\title{
EPISCOPUS, PRESBYTER, SACERDOS, DIACONUS: NIEKTÓRE WYJAŚNIENIA PAPIEŻA INNOCENTEGO I W LIŚCIE DO DECENCJUSZA, BISKUPA GUBBIO
}

Św. Innocenty I był biskupem Rzymu od 22 grudnia 401 r. do 12 marca $417 \mathrm{roku}^{1}$. Liber pontificalis precyzuje, że pełnił ten urząd 15 lat, dwa miesiące i 21 dni, że troszczył się o dobro całego Kościoła, że położył duże zasługi dla rozwoju zakonów oraz że uznał za heretycką naukę Pelagiusza i Celestiusza². Był wytrwałym i zdecydowanym obrońcą tradycyjnej nauki apostolskiej, podejmując nie bez odwagi kwestie natury teologicznej, moralnej i liturgicznej, uwzględniając konkretne potrzeby wiernych, dostrzegane przez samego siebie albo zgłaszane przez biskupów. Szczególnym świadectwem tego typu działalności jest 36 jego listów, wśród których na wyjątkową uwagę zasługuje List do Decencjusza, biskupa Gubbio ${ }^{3}$. O samym adresacie pisma mamy doprawdy skąpe informacje. Prestiżowy włoski słownik patrystyczny pod hasłem $D e-$ cenzio di Gubbio podaje jedynie przybliżoną datę śmierci biskupa (po 416 r.), następnie wyjaśnia, że jest on znany wyłącznie dzięki wspomnianemu listowi Innocentego I; ten zaś został zredagowany w odpowiedzi na pytania skierowane przez biskupa do papieża, dotyczące przede wszystkim niektórych kwestii

*Ks. dr hab. Waldemar Turek - professore invitato na Pontificia Università Urbaniana w Rzymie, pracownik Sekretariatu Stanu Stolicy Apostolskiej; e-mail: turek@tiscalinet.it.

${ }^{1}$ Por. Annuario Pontificio 2016, Città del Vaticano 2016, 9*. Kwestia podania dokładnej daty początku pontyfikatu Innocentego I nie wydaje się zakończona, jak wynika choćby z najnowszego wydania prestiżowego opracowania: Ph. Jaffé, Innocentius I, in: Regesta Pontificum Romanorum. Ab condita Ecclesia ad annum post Christum natum MCXCVIII, Editionem tertiam emendatam et auctam iubente Academia Gottingensi, I (A s. Petro usque ad A. DCIV), curavit M. Schütz, Gottingae MMXVI, 122; autorzy wskazując na rok 401 jako chronologiczny początek pontyfikatu papieża, dodają znak zapytania.

${ }^{2}$ Por. LP I 220: ,Innocentius, natione Albanense, ex patre Innocentio, sedit ann. XV m. II d. XXI. Hic constitutum fecit de omnem ecclesiam et de regulis monasteriorum et de Iudaeis et de paganis et multos Catafrigas invenit, quos exilio monasterii religavit. Hic invenit Pelagium et Caelestium hereticos et damnavit eos". Podstawowe wiadomości o życiu i działalności Innocentego I można znaleźć w: B. Studer, Innocenzo I papa, NDPAC II 2563-2564.

${ }^{3}$ Por. Innocentius I, Epistula ad Decentium episcopum Egubinum w. 1-154, ed. R. Cabié: La Lettre du Pape Innocent I Ir a Décentius de Gubbio (19 Mars 416), Bibliothéque de la Revue d'Histoire Ecclésiastique 58, Louvain 1973 [wszystkie polskie przekłady cytowanych fragmentów listu pochodzą od autora]. 
liturgicznych ${ }^{4}$. Nie dysponujemy, niestety, tekstem pytań skierowanych przez biskupa Gubbio do Innocentego I; ich treści możemy się jedynie domyślać, analizując wyjaśnienia papieża.

List był analizowany z różnych punktów widzenia, w sposób szczególny pod kątem dominujących w nim aspektów związanych z liturgią․ Dostarcza on jednak także sporo danych, na podstawie których można próbować opisać niektóre zadania i kompetencje głównych przedstawicieli ówczesnej hierarchii kościelnej. Chodzi przede wszystkim o tych duchownych, do których Innocenty I odnosi tytuły: episcopus, presbyter ${ }^{6}$, sacerdos i diaconus ${ }^{7}$. Analizując kontekst historyczny, liturgiczny i teologiczny ich użycia, z uwzględnieniem niektórych innych tekstów pochodzących z tego okresu, postaram się uściślić niektóre prawa i obowiązki ówczesnego kleru w ujęciu papieża Innocentego I. Biorąc pod uwagę dane statystyczne, można podać następujący zestaw odnośnych terminów użytych w liście: episcopus (słowo występuje 15 razy), presbyter (9 razy), sacerdos ( 8 razy), diaconus $\left(2\right.$ razy) ${ }^{8}$. Jest rzeczą charakterystyczną, że w liście nie ma żadnego tytułu, którym Innocenty I określałby pełniony przez siebie urząd biskupa Rzymu. Ma on jednak wyraźnie świadomość szczególnej misji, jaką sprawuje we wspólnocie rzymskiej i w odniesieniu do innych biskupów i wiernych. Wydaje się rzeczą uzasadnioną rozpocząć część istotną tego opracowania właśnie od tego tematu.

\section{Innocenty I o piastowanym przez siebie urzędzie biskupa Rzymu.} Od początku listu jego autor, wykazując troskę o jednolitość w zwyczajach i obrzędach liturgicznych, postrzega kierowaną przez siebie wspólnotę jako model, który ma być punktem odniesienia dla innych pasterzy i wiernych:

${ }^{4}$ Por. V. Saxer - S. Heid, Decenzio di Gubbio, NDPAC I 1344-1345.

${ }^{5}$ Mam na uwadze głównie szczegółowe analizy autorstwa G. Malchiodi i R. Cabié, które wykorzystuję w dalszej części niniejszego opracowania. Stanowią one podstawowe wyjaśnienia, w języku włoskim i francuskim, głównych tematów liturgicznych poruszanych przez św. Innocentego I w liście do Decencjusza, biskupa Gubbio. W opracowaniu R. Cabié znajdujemy dodatkowo (s. 1-17) szczegółowe informacje na temat tradycji manuskryptów przekazujących tekst listu. Jako wprowadzenie zarówno w tematykę liturgiczną listu jak i w opracowania w języku angielskim, zob. M.F. Connell, Church and Worship in Fifth-Century Rome: The Letter of Innocent I to Decentius of Gubbio, Text with Introduction, Translation and Notes, Joint Liturgical Studies 52, Cambridge 2002. Nie są mi natomiast znane opracowania w języku polskim (poza sporadycznymi wzmiankami i cytatami), które odnosiłyby się bezpośrednio do interesującego nas listu papieża Innocentego I.

${ }^{6}$ Łacina pierwszych wieków chrześcijaństwa używała klasycznej wersji presbyter; w opracowaniu używam tej pisowni, mimo że wydawca listu podaje formę presbiter.

${ }^{7}$ Gdy chodzi o bibliografię dotyczącą tych tytułów i związanych z nimi tematów w epoce starożytnej, zob.: E. Stanula, Patrystyczna literatura o kaptaństwie (przeglad bibliograficzny), VoxP 13-15 (1993-1995) t. 24-29, 49-58; S. Longosz, Bibliografia. Kapłaństwo w starożytności chrześcijańskiej, VoxP 13-15 (1993-1995) t. 24-29, 499-555.

${ }^{8}$ Por. R. Cabié, Table des mots latins, w: La Lettre du Pape Innocent I Ir a Décentius de Gubbio, s. 64-66. 
„Któż bowiem nie wie albo nie dostrzega, że to, co przez Piotra, księcia apostołów, zostało przekazane Kościołowi Rzymskiemu (Romanae ecclesiae traditum est), i czego się aż do tej pory strzeże, powinno być przez wszystkich zachowywane, i nie powinno się dodawać albo wprowadzać czegoś, co albo nie ma powagi albo wydaje się brać wzór skądinąd"9.

Przytoczone stwierdzenie nie odnosi się jedynie do wspólnoty Gubbio, ale ukazuje pewien styl Innocentego I, który przed ustosunkowaniem się do konkretnych kwestii podniesionych przez Decencjusza, podaje niektóre przesłanki o charakterze historycznym i teologicznym. Dostrzega się zatem przede wszystkim odwołanie do autorytetu św. Piotra i do tego wszystkiego, co on przekazał Kościołowi Rzymskiemu i co ma być wiernie przestrzegane. Co więcej, biskup Rzymu zaznacza, że nie powinno się do tego dziedzictwa dodawać czegokolwiek albo wprowadzać czegokolwiek, co nie ma uzasadnienia albo ma swoje źródło gdzie indziej. Użyty w przytoczonym sformułowaniu termin exemplum odnosi się pośrednio do Kościoła Rzymskiego, ukazanego jako wzór do naśladowania przez inne wspólnoty. Szczególnie biskupi Zachodu mają obowiązek śledzić we wszystkich przejawach życia model Kościoła Rzymskiego:

„Zwłaszcza że, jak dokładnie wiadomo, w całej Italii, w Galii, Hiszpanii, Afryce oraz na Sycylii i na wyspach leżących pomiędzy nimi nikt inny nie założył Kościołów, jak tylko ci, których czcigodny apostoł Piotr albo jego następcy ustanowili biskupami" ${ }^{\prime 10}$.

Dla Innocentego I jest rzeczą oczywistą, że we wszystkich wymienionych regionach jest powszechnie wiadomo, że nie kto inny tylko św. Piotr założył te Kościoły. $Z$ tego jasno wynika, że wszyscy wierni zamieszkujący te ziemie powinni traktować jako wzorcową wspólnotę, z którą są związani przez posługę Apostoła; w ten sposób będzie zachowana tak bardzo potrzebna jednolitość między chrześcijanami ${ }^{11}$. Innocenty I nie wchodzi w szczegóły historyczne,

${ }^{9}$ Innocentius I, Epistula ad Decentium w. 12-16, ed. Cabié, s. 18: „Quis enim nesciat aut non advertat id quod a principe apostolorum Petro Romanae ecclesiae traditum est, ac nunc usque custoditur ab omnibus debere servari nec superduci aut introduci aliquid quod auctoritatem non habeat, aut aliunde accipere videatur exemplum". Por. G. Malchiodi, La Lettera di S. Innocenzo I a Decenzio vescovo di Gubbio. Breve studio esegetico-storico, Roma 1921, 19: „È evidente che il Sommo Pontefice, con ciò, vuol dire che la fondazione di una Chiesa porta seco il culto divino e quindi le regole liturgiche ad esso congiunte e, per conseguenza, si deve seguire la Chiesa Romana nella liturgica, perché l'amore alle novità non faccia dimenticare la principale delle istituzioni”".

${ }_{10}$ Tamże w. 16-20, ed. Cabié, s. 18-20: „Praesertim cum sit manifestum in omnem Italiam, Gallias, Spanias, Africam atque Siciliam et insulas interiacentes nullum instituisse ecclesias, nisi eos quos venerabilis apostolus Petrus aut eius successores constituerint sacerdotes".

${ }^{11}$ Por. V. Monachino, La Lettera decretale di Innocenzo I a Decenzio vescovo di Gubbio, w: Ricerche sull'Umbria tardoantica e preromanica. Atti del II Convegno di Studi Umbri, Gubbio 24-28 maggio 1964, Gubbio 1965, 217: „Evidentemente, tale uniformità si ottiene prendendo a modello la Chiesa Romana, la quale ha ricevuto le sue istituzioni dal Principe degli Apostoli, Pietro, e le custodisce tuttora gelosamente". 
raczej wybiera stwierdzenie o charakterze ogólnym; św. Piotr ewangelizował Zachód i założył osobiście Kościół Rzymski. Wszystkie Kościoły istniejące na Zachodzie korzeniami sięgają działalności tego Apostoła albo biskupów przez niego ustanowionych, albo ich następców. Papież Innocenty, po ukazaniu szczególnego miejsca Kościoła Rzymskiego, zwraca się bezpośrednio do Decencjusza, przypominając mu jego wizyty w Rzymie i udział w celebracjach, którym papież przewodniczył:

„Nie ma wątpliwości, że Twoja Miłość przybywał często do Rzymu i spotykał się z nami w Kościele [na nabożeństwach], i wie jaki zwyczaj zachowuje on w celebracjach eucharystycznych albo w sprawowaniu innych obrzędów [liturgicznych]"12.

W takim razie, zauważa Innocenty I, ponieważ Decencjusz zna zwyczaje rzymskie w celebrowaniu Mszy świętej, w administrowaniu sakramentów i w innych obrzędach liturgicznych, to już wystarczyłoby aby odrzucić zmiany wprowadzone przez jego poprzedników. Zupełnie jednak rozumie i aprobuje sposób postępowania Decencjusza, który prosi o wyjaśnienia; pragnie on odwołać się do szczególnego autorytetu, jakim cieszy się biskup Rzymu:

„Odpowiemy na nie zatem nie dlatego, abyśmy myśleli, że nie wiesz pewnych rzeczy, ale dlatego, abyś z większym autorytetem czy to pouczył twoich [wiernych] czy też, jeśli niektórzy błądzą [odchodząc] od zwyczajów obowiązujących w Kościele Rzymskim, ich upomniał, albo nie zwlekając ich wskazał, abyśmy mogli wiedzieć kim są ci, którzy wprowadzają nowe rzeczy albo uważają, że należy zachowywać zwyczaje Kościoła innego niż Rzymski”'13.

Papież ukazuje szczególne zadania powierzone biskupowi Decencjuszowi, jak i innym biskupom głoszącym Ewangelię w różnych regionach: pouczenie wiernych, upomnienie odchodzących, wreszcie wskazanie mu nowinkarzy, aby mógł podjąć stosowne działanie. Innocenty I zobowiązuje Decencjusza nie tylko do tego, aby dostosował się do podanych wskazówek, ale wyposaża go w odpowiedni dokument, którym będzie on mógł się posługiwać zarówno w kontaktach z własnym duchowieństwem jak i tymi wszystkimi, których będzie spotykał. Prosząc go następnie o to, aby wskazał mu ewentualnych winnych, czyli tych, którzy wprowadzili albo zamierzają wprowadzić nowinki, ustanawia go swoim współpracownikiem w dziele ujednolicania, które on sam zamierza realizować. W zakończeniu listu Innocenty I raz jeszcze przypomina biskupowi Decencjuszowi, że jego Kościół pochodzi od tego rzymskiego i ma

${ }^{12}$ Innocentius I, Epistula ad Decentium w. 25-28, ed. Cabié, s. 20: „Saepe dilectionem tuam ad Urbem venisse, ac nobiscum in ecclesia convenisse, non dubium est, et quem morem vel in consecrandis mysteriis, vel in caeteris agendis arcanis teneat cognovisse".

${ }^{13}$ Tamże w. 30-37, ed. Cabié, s. 20: „Quibus idcirco respondemus, non quod te aliqua ignorare credamus, sed ut maiore auctoritate vel tuos instituas, vel si qui a Romanae ecclesiae institutionibus errant, aut commoneas aut indicare non differas, ut scire valeamus qui sint qui aut novitates inducunt aut alterius ecclesiae quam Romanae existimant consuetudinem esse servandam". 
obowiązek strzec i zachowywać tradycję rzymską, czyli troszczyć się w sposób szczególny o jednolitość w obrzędach liturgicznych:

„Staraliśmy się więc, Drogi Bracie, na ile potrafiliśmy, odpowiedzieć na to wszystko, co Twoja Miłość chciał, aby zostało przez nas wyjaśnione, aby Kościół twój mógł zachować i strzec rzymską tradycję, z której bierze początek" "14.

Gdy chodzi o inne sprawy, co do których, z różnych powodów, nie można było się ustosunkować pisemnie, papież obiecuje, że wyjaśni swoje stanowisko przy najbliższym bezpośrednim spotkaniu z biskupem Decencjuszem. List kończy krótkie wezwanie do Boga, aby dopomógł Decencjuszowi kierować Kościołem w Gubbio i właściwie formować duchownych; nie bez powodu wymienia się też w tym kontekście posługi liturgiczne, którym w przeważającej mierze list jest poświęcony:

„Jeśli zaś chodzi o inne kwestie, na które nie można było odpowiedzieć pisemnie, gdy będziesz obecny i o nie nas zapytasz, będziemy mogli je przedstawić. A Pan niech sprawi swoją mocą także to, żebyś dobrze uformował i twój Kościół i naszych duchownych, którzy pod twoją biskupią władzą sprawują posługi liturgiczne, i innym dał wzór, który powinni naśladować"15.

Innocenty I ma świadomość wyjątkowości piastowanego przez siebie urzędu i szczególnego miejsca, jakie zajmuje w Kościele, zwłaszcza Zachodnim, kierowana przez niego wspólnota rzymska. Podkreśla przede wszystkim jej szczególne związki z apostołem Piotrem i przedstawia ją zdecydowanie jako model, na który mają patrzeć inne Kościoły, zwłaszcza w sprawach liturgii. Jeśli będą one tak postępowały, będą zachowywane w zasadniczej mierze wierność, jedność i jednolitość między wyznawcami Chrystusa, zamieszkującymi różne regiony.

2. Episcopus. Jest to termin, którego papież Innocenty I używa najczęściej w swoim Liście do Decencjusza, biskupa Gubbio w odniesieniu do ówczesnej hierarchii kościelnej. Można bez przesady powiedzieć, że list ten jest przede wszystkim listem do biskupa i listem o biskupach: ich władzy, uprawnieniach i obowiązkach $\mathrm{w}$ dziedzinie liturgii. Już pierwsze użycie słowa episcopus jest bardzo znamienne. Papież pisze:

„Jasną jest rzeczą że gdy chodzi o bierzmowanie dzieci, nie wolno tego czynić nikomu poza biskupem (episcopo). Prezbiterzy (presbyteri) bowiem, cho-

${ }^{14}$ Tamże w. 144-147, ed. Cabié, s. 32: „His igitur, frater carissime, omnibus quae tua dilectio voluit a nobis exponi prout potuimus respondere curavimus, ut ecclesia tua Romanam consuetudinem a qua originem ducit servare valeat atque custodire".

${ }^{15}$ Tamże w. 147-152, ed. Cabié, s. 32: „Reliqua vero quae scribi fas non erat, cum adfueris interrogati poterimus edicere. Erit autem Domini potentiae etiam id procurare ut et tuam ecclesiam et clericos nostros qui sub tuo pontificio divinis famulantur officiis bene instituas et aliis formam tribuas quam debeant imitari". 
ciaż są kapłanami (sacerdotes), nie mają jednak najwyższego stopnia kapłaństwa (pontificatus tamen apicem non habent)" ${ }^{\prime \prime 6}$.

Wydaje się rzeczą pożyteczną, przed uwzględnieniem interesujących nas w sposób szczególny terminów episcopus i sacerdos, zwrócić uwagę na użyty w tym samym zdaniu czasownik consignare; w całym liście Innocentego I pojawia się on trzykrotnie ${ }^{17}$. W łacinie klasycznej tłumaczy się go zwykle słowami: „podpisać, oznaczyć, opatrzyć pieczęcią". W łacinie chrześcijańskiej wskazuje, w sensie dosłownym, m.in., na czynienie znaku krzyża na kimś albo na czymś. Taki sens można dostrzec np. w następującym zdaniu św. Hieronima, autora współczesnego św. Innocentemu I:

„Gdy tam przybył, uczyniwszy znak krzyża (consignans) nad łóżkiem każdego i na częściach ich ciał ogarniętych gorączka, wezwał Pana"18.

Ten sam termin w przytoczonym wyżej zdaniu św. Innocentego jest użyty, aby wskazać na administrowanie sakramentu bierzmowania ${ }^{19}$. W nieco wyżej przytoczonym tekście Innocenty I odpowiada na pytanie bądź pytania Decencjusza, które mogły dotyczyć samego szafarza tego sakramentu jak też innych kwestii z nim związanych. Biskup Rzymu jasno precyzuje, że bierzmowanie może być udzielane jedynie przez biskupa, podając jednocześnie uzasadnienie teologiczne tego stanowiska: prezbiterzy, chociaż są kapłanami, nie mają najwyższego stopnia kapłaństwa (pontificatus). Zaraz w następnym zdaniu właśnie do biskupów odnosi termin pontifex:

„To zaś, że sami biskupi (pontificibus) powinni bierzmować albo przekazywać Ducha Świętego, pokazuje nie tylko zwyczaj kościelny, lecz także tekst Dziejów Apostolskich podający, że Piotr i Jan zostali posłani, aby już ochrzczonym udzielić Ducha Świętego (por. Dz 8, 14-17)"’20.

Biskupi są postawieni najwyżej w hierarchii kościelnej; ich rola i funkcje wynikają zarówno z Pisma Świętego jak i z Tradycji. Św. Innocenty podaje tutaj jako przykład wypowiedź z Dziejów Apostolskich ukazującą dwóch apostołów (Piotra i Jana) posłanych, aby już ochrzczonym udzielić Ducha Świętego. Nie wydaje się rzeczą przypadkową odwołanie się właśnie do tego tekstu,

${ }^{16}$ Tamże w. 53-55, ed. Cabié, s. 22: „De consignandis vero infantibus manifestum est non ab alio quam ab episcopo fieri licere. Nam presbyteri licet sint sacerdotes, pontificatus tamen apicem non habent".

${ }^{17}$ Por. Cabié, Table des mots latins, s. 63.

${ }^{18}$ Hieronymus, Vita Hilarionis VIII 8, ed. B. Degórski, Hieronymi Opera XV, Roma 2014, 132: „Quo postquam venit, singulorum lectulos et ardentia membra consignans, invocavit Iesum”, thum. własne.

${ }^{19}$ Por. Blaise, s. 205-206, s.v. Consigno, -are.

${ }^{20}$ Innocentius I, Epistula ad Decentium w. 55-59, ed. Cabié, s. 22-24: „Hoc autem pontificibus solis deberi, ut vel consignent, vel paracletum Spiritum tradant non solum consuetudo ecclesiastica demonstrat, verum illa lectio Actuum apostolorum quae asserit Petrum et Iohannem esse directos qui iam baptizatis tradant Spiritum sanctum". 
aby pośrednio ukazać, że to biskupi są następcami apostołów. O roli biskupa mówi Innocenty I także w następnych zdaniach, w których aż czterokrotnie posługuje się rzeczownikiem episcopus. Papież precyzuje tutaj normy dotyczące użycia krzyżma w czasie udzielania chrztu świętego i bierzmowania:

„Prezbiterom bowiem, którzy chrzczą czy to pod nieobecność biskupa (extra episcopum), czy też w jego obecności (praesente episcopo), wolno ochrzczonych namaszczać krzyżmem, lecz takim, które zostało poświęcone przez biskupa (ab episcopo). Nie [wolno im] jednak tymże olejem znaczyć czoła [jak przy bierzmowaniu], co przysługuje samym biskupom (episcopis), kiedy przekazują Ducha Świętego" "21.

Pobieżna lektura tego stwierdzenia św. Innocentego I mogłaby sugerować, jak już było wspomniane, że biskup Decencjusz prosił o wyjaśnienie, kto jest zwykłym szafarzem bierzmowania. Nie wydaje się jednak, jak wynika z kontekstu całego listu, że były w tej mierze jakieś wątpliwości ze strony pasterza Gubbio; można przypuszczać, że zarówno autor listu jak i jego adresat są w tej kwestii jednomyślni. Wątpliwości Decencjusza dotyczyły raczej innego zagadnienia: namaszczenie na czole dokonywane w kształcie znaku krzyża jest w gestii biskupów, którzy udzielają Ducha Świętego, czy też prezbiterów, którzy udzielają chrztu świętego? Odpowiedź papieża jest jednoznaczna: chodzi o element bierzmowania, którego udzielanie przysługuje jedynie biskupom ${ }^{22}$.

Pozostając przy znaku krzyża, ale wykonywanego już w zupełnie innym kontekście, św. Innocenty I znowu mówi o szczególnej roli, jaką w życiu wspólnot kościelnych odgrywają biskupi. Tym razem nie trzeba się domyślać pytania Decencjusza, bo sam autor listu referuje je w swojej odpowiedzi:

„Odnośnie do tych ochrzczonych, którzy potem wskutek jakiegoś nałogu albo grzechu są opętani przez demona, Twoja Miłość pytał mnie, czy mogą albo powinni być naznaczeni krzyżem (consignari) przez prezbitera (presbytero) albo diakona (diacono). Nie wolno tego czynić, jeśli biskup (episcopum) nie poleci. Albowiem zupełnie nie wolno nałożyć na niego ręki, jeśli biskup (episcopus) nie udzieli pozwolenia na uczynienie tego"23.

${ }^{21}$ Tamże w. 60-64, ed. Cabié, s. 24: „Nam presbyteris seu extra episcopum seu praesente episcopo cum baptizant, chrismate baptizatos unguere licet, sed quod ab episcopo fuerit consecratum, non tamen frontem eodem oleo signare, quod solis debetur episcopis cum tradunt Spiritum paracletum".

${ }^{22}$ Por. R. Cabié, La Lettre „Si instituta” dans l'histoire de la liturgie, w: La Lettre du Pape Innocent I I r a Décentius de Gubbio, s. 47: „Mais il s'agissait de savoir si l'onction sur le front en signe de croix revenait «aux évêques quand ils donnent l'Esprit Paraclet» ou aux «prêtres quand ils baptisent». La question peut être ainsi précisée à la lumière de la liturgie gallicane, que le contexte général du document nous autorise à invoquer ici. La réponse du pape est nette: solis debetur episcopis".

${ }^{23}$ Innocentius I, Epistula ad Decentium w. 102-107, ed. Cabié, s. 28: „De his vero baptizatis qui postea a daemonio, vitio aliquo aut peccato interveniente, arripiuntur, quaesivit dilectio tua si a presbytero vel diacono possint aut debeant consignari. Quod hoc nisi episcopum praecipere non licet. Nam ei manus imponenda omnino non est nisi episcopus auctoritatem dederit id efficiendi”. 
Rzecz dotyczy osób ochrzczonych, które znalazły się pod szczególną mocą szatana; można domyślać się, że chodzi tutaj o rodzaj opętania. Decencjusz, jeśli chcemy spróbować sprecyzować jego pytanie, mógł prosić o rzecz następującą: czy nałożenie rąk przez kapłana bądź diakona na ochrzczonego opętanego (egzorcyzm?) wymaga pozwolenia ze strony biskupa? Odpowiedź papieża także w tym wypadku jest jasna: nie wolno tego czynić prezbiterowi albo diakonowi, jeśli nie zezwoli na to biskup. Jeśli jednak biskup udzieli takiego zezwolenia, znak może być uczyniony zarówno przez prezbitera jak nawet przez innych duchownych, określanych tutaj wyrażeniem ceteris clericis.

„Aby zaś to się stało, do biskupa należy zarządzić, aby prezbiter albo pozostali duchowni włożyli na niego rękę"24.

Wyjaśnienia Innocentego I nie zaskakują jeśli weźmie się pod uwagę fakt, że już w pierwszych wiekach chrześcijaństwa ryty uwalniania osób będących pod szczególnym wpływem szatana były praktykowane przez zwykłych wiernych odznaczających się specjalnym charyzmatem. Później tego typu zadania należały do kompetencji duchownych niższych stopni zwanych egzorcystami; ustanawiano ich aby wzmocnić ich autorytet oraz aby bronić wiernych przed fałszywymi egzorcystami. Pozostawało jednak rzeczą ciagle skomplikowaną odróżnienie prawdziwych przypadków opętania od innych zjawisk patologicznych, zwłaszcza epilepsji. Próbowano zatem zapobiec różnym nadużyciom przez zarezerwowanie biskupom tej szczególnej materii: to oni mieli decydować, kiedy było to możliwe, w poszczególnych przypadkach, czy i kto ma dokonać rytu. Biskup mógł uczynić to osobiście bądź delegować kogoś do konkretnego przypadku. Wydaje się, że pytanie Decencjusza i odpowiedź Innocentego I przypadają właśnie na ten etap praktyki w odniesieniu do osób opętanych $^{25}$. Biskup Rzymu opowiada się zdecydowanie za pewnym unormowaniem tej sprawy, z możliwością jednak udzielania delegacji odnośnym duchownym. Podaje tutaj względy czysto praktyczne:

„Mogłoby bowiem bez większych trudności zdarzyć się, że człowiek opętany przez złego ducha, mieszkający daleko, byłby prowadzony do biskupa (episcopum), i gdyby miał atak [opętania] w drodze, nie byłoby można ani doprowadzić go do biskupa (episcopum), ani odprowadzić łatwo do jego domu"26.

${ }^{24}$ Tamże w. 107-108, ed. Cabié, s. 28: „Ut autem fiat episcopi est imperare ut manus ei vel presbytero vel a caeteris clericis imponatur".

${ }^{25}$ Zob. Monachino, La Lettera decretale, s. 217: „Restava però spesso difficile distinguere i veri casi di ossessione da altri fenomeni patologici specie epilettici. Si cercò di rimediare col riservare al vescovo tutta la delicata materia: spettava a lui decidere, in quanto era possibile, sul fatto dell'ossessione, come anche il compiere gli esorcismi o delegare a ciò qualche altro membro del clero".

${ }^{26}$ Innocentius I, Epistula ad Decentium w. 108-112, ed. Cabié, s. 28: „Nam quomodo id fieri sine magno labore poterit ut longe constitutus energumenus ad episcopum deducatur, cum si talis casus ei in itinere acciderit, nec perferri ad episcopum, nec referri ad sua facile possit?". 
Nieco odmienne kwestie dotyczące uprawnień biskupa i innych duchownych podejmuje Innocenty I w części listu poświęconej modlitwie za chorych. Najpierw zauważa:

„Nie ma wątpliwości, że trzeba przyjąć i rozumieć, że jest tu mowa o chorujących wiernych, którzy mogą być namaszczeni świętym olejem namaszczenia, poświęconym przez biskupa (ab episcopo), którego nie tylko kapłanom ( $\mathrm{s} a-$ cerdotibus), lecz i wszystkim chrześcijanom wolno używać do namaszczenia, w potrzebie własnej lub swoich bliskich"27.

Papież odnosi początkowe wyrażenie przytoczonego tekstu, czyli „Nie ma wątpliwości”, do tekstu z Listu św. Jakuba apostoła, przytaczanego tutaj w wersji Innocentego I, różniącej się nieco od tej, którą czyta się we współczesnym wydaniu Biblii:

„Jeśli ktoś wśród was jest chory, niech wezwie kapłanów (presbyteros) i niech pomodlą się nad nim, namaszczając go olejem w imię Pańskie, a modlitwa [płynąca z wiary] wybawi chorego i podźwignie go Pan. A jeśli popełnił grzech, odpuści mu (por. Jk 5, 14-15)"’28.

Można przypuszczać, że Decencjusz pytając biskupa Rzymu o to, kto może namaszczać olejem chorych i kogo (wiernych, nie katechumenów, pokutujących?) przytoczył znany tekst biblijny prosząc o wskazówki co do jego właściwej interpretacji. Może nieco zaskakiwać fakt, że Decencjusz miał tutaj pewne wątpliwości w odniesieniu do uprawnień biskupa. Być może, niektórzy wierni jego diecezji powoływali się na przytoczone zdanie apostoła Jakuba, który użył w nim terminu presbyteri a nie episcopi $i^{29}$. Papież Innocenty I odpowiada w sposób jednoznaczny:

„Zbyteczne zresztą - jak sądzimy - zostało dodane to, że istnieją wątpliwości co do uprawnień biskupa (episcopo) w tym, co niewattpliwie wolno kapłanom (presbyteris). Bo dlatego jest powiedziane o prezbiterach (presbyteris), po-

${ }^{27}$ Tamże w. 129-133, ed. Cabié, s. 30: „Quod non est dubium de fidelibus aegrotantibus accipi vel intelligi debere qui sancto oleo chrismatis perungui possunt quod ab episcopo confectum non solum sacerdotibus sed et omnibus uti christianis licet, in sua aut in suorum necessitate unguendum”.

${ }^{28}$ Tamże w. 126-129, ed. Cabié, s. 30: „Si infirmus aliquis in vobis est vocet presbiteros et orent super ipsum, unguentes eum oleo in nomine domini et orati fidei salvabit laborantem et suscitabit illum dominus et si peccatum fecit, remittet ei”.

${ }^{29}$ Warto w tym miejscu przytoczyć uwagi dotyczące aspektów biblijnych tych dwóch tytułów (presbyteri i episcopi) pojawiających się razem w Dziejach Apostolskich (15, 2. 4. 6. 22-23;16, 4); zob. A. Lemaire, Les ministères aux origines de l'Église. Naissance de la triple hiérarchie: évêques, presbytres, diacres, Lectio Divina 68, Paris 1971, 183: „Les «presbytres» sont les chefs de l'église locale de Jérusalem et les «apôtres» probablement des missionnaires itinérants venant surtout d'Antioche. L'expression double «apôtres et presbytres» ne fait donc que souligner l'accord intervenu entre les deux parties et ne constitue qu'un rapprochement accidentel des deux titres". 
nieważ biskupom (episcopi) przeszkadzają inne zajęcia i nie mogą oni udawać się do wszystkich chorych"30.

Papież Innocenty zwraca zatem uwagę znowu na względy praktyczne i liczne obowiązki, które sprawiają, że biskupi nie mogą się udawać do wszystkich chorych; przekracza to znacznie ich możliwości fizyczne. Ale oczywiście są oni uprawnieni do tego, aby modlić się za chorych i namaszczać ich świętym olejem, zwłaszcza wtedy, gdy pozwalają im na to codzienne obowiązki albo gdy chodzi o osobę szczególnie zasłużoną dla wspólnoty wierzących:

„Zresztą, jeśli biskup (episcopus) ma możliwość albo sądzi, że ktoś zasługuje na to, by on sam go odwiedził, wówczas może bez wahania i błogosławić i namaszczać olejem, bo do niego należy poświęcić olej”31.

Przytoczony tekst, z którego jasno wynika, że święcenie oleju należy do uprawnień biskupa, stanowi ostatni fragment listu, w którym jego autor posługuje się terminem episcopus. Użył go po raz pierwszy w odniesieniu do bierzmowania, następnie tłumacząc niektóre kwestie związane ze chrztem świętym, później słowo pojawiło się we fragmencie dotyczącym uwalniania opętanych, wreszcie w zdaniach odnoszących się do sakramentu chorych.

3. Presbyter. Innocenty I posługując się rzeczownikiem presbyter, używa słowa, które wcześniej zostało zapożyczone od chrześcijan języka greckiego; termin nie był bowiem znany w łacinie klasycznej. Tłumacze łacińscy Biblii, kiedy napotykali w tekście greckim to słowo w znaczeniu starszych, thumaczyli je jako seniores, senes, maiores natu; kiedy natomiast postrzegali, że chodzi o urząd kapłański, pozostawiali wyrażenie w brzmieniu greckim używając liter łacińskich: presbyter $i^{32}$. W niniejszym opracowaniu zostały już przytoczone niektóre fragmenty listu Innocentego I, w których posługuje się on rzeczownikiem presbyter; szczególnie znaczące okazało się zdanie, z którego wynika, że prezbiterzy (presbyteri), chociaż są kapłanami (sacerdotes), nie mają najwyższego stopnia kapłaństwa (pontificatus apicem non habent) ${ }^{33}$. Cytowany też był fragment, w którym papież posługuje się zarówno terminem

${ }^{30}$ Innocentius I, Epistula ad Decentium w. 134-137, ed. Cabié, s. 30: „Caeterum illud superfluum videmus adiectum, ut de episcopo ambigatur, quod presbyteris licere non dubium est. Nam idcirco presbyteris dictum est, quia episcopi, occupationibus aliis impediti, ad omnes languidos ire non possunt".

${ }^{31}$ Tamże w. 137-140, ed. Cabié, s. 30: „Caeterum si episcopus aut potest aut dignum ducit aliquem a se visitandum, et benedicere et tangere chrismate sine cunctatione potest, cuius est ipsum chrisma conficere".

${ }^{32}$ Por. E. Cattaneo, Introduzione generale, w: I ministeri nella Chiesa Antica. Testi patristici dei primi tre secoli, a cura di E. Cattaneo, Letture cristiane del primo millennio 25, Milano 1997, 36. Autor wyjaśnia także (tamże, s. 37-38) pewien fenomen językowy: w pierwszych wiekach chrześcijaństwa w tekstach łacińskich rozróżniano znaczeniowo presbyter i sacerdos. Dopiero w późnym okresie patrystycznym niektórzy autorzy niekiedy zaczęli utożsamiać te dwa określenia.

${ }^{33}$ Por. Innocentius I, Epistula ad Decentium w. 54-55, ed. Cabié, s. 22. 
presbyter jak episcopus w kontekście swojej wykładni dotyczącej namaszczania krzyżmem ${ }^{34}$. W nieco innym natomiast kontekście pojawia się ten termin, kiedy biskup Rzymu traktuje o chlebie eucharystycznym, posyłanym do prezbiterów w obrębie miasta:

„Kapłani (presbyteri), którzy tego dnia, ze względu na lud sobie powierzony, nie mogą celebrować razem z nami, otrzymują dlatego przez akolitów chleb eucharystyczny przez nas konsekrowany (fermentum), aby nie czuli się, zwłaszcza tego dnia, wyłączeni z naszej wspólnoty"35.

Z tekstu wynika, że prezbiterzy są tymi, którym powierzono duszpasterską troskę o wiernych. Poprzednie zdanie listu informuje nas o tym, że sprawują oni swoją posługę wewnątrz murów tego samego miasta i że w niedzielę posyłany jest do nich przez samego biskupa chleb eucharystyczny, czyli fermentum $^{36}$. Nie moga oni bowiem, z racji na posługę na rzecz powierzonych sobie wiernych, celebrować Eucharystii z biskupem, z którym tworzą tę samą wspólnotę. Przekazywanie chleba eucharystycznego było znakiem troski biskupa Rzymu o podtrzymywanie i pogłębianie tejże wspólnoty. Innocenty I wskazuje jednak wyraźnie na fakt, że ten ryt dotyczy prezbiterów zamieszkujących miasto. To oni, na mocy wynikającej z prawa, są koncelebransami mszy stacyjnej, której przewodniczy biskup. Może się jednak zdarzyć, że nie mogą brać w niej udziału z racji na powierzone im obowiązki na konkretnych placówkach duszpasterskich (propter plebem sibi creditam).

Warto zaznaczyć, że w odniesieniu do tych stacji papież nie używa słowa „parafia”. Być może, chce przez to powiedzieć, że on jest jedynym „,proboszczem" Rzymu i że zależy mu na tym, aby właśnie przez Eucharystię sprawowaną z fermentum była ukazana jedność między nim i prezbiterami posługującymi w różnych dzielnicach Rzymu ${ }^{37}$. Słowo bowiem parrochia pojawia się w następnym zdaniu, odnoszonym do sytuacji wspólnoty kościelnej w Gubbio, w którym to zdaniu dwukrotnie dostrzega się też rzeczownik presbyter:

„Nie uważam jednak, że powinno to się dziać w odniesieniu do odległych parafii (per parrochias), ponieważ ani sakramenty nie powinny być przenoszone daleko, ani też my nie posyłamy go prezbiterom (presbyteris) ustano-

${ }^{34}$ Por. tamże w. 60-64, ed. Cabié, s. 24.

35 Tamże w. 94-98, ed. Cabié, s. 26: „Presbyteri, quia die ipsa propter plebem sibi creditam nobiscum convenire non possunt, idcirco fermentum a nobis confectum per acolitos accipiunt, ut se a nostra communione maxime illa die non iudicent separatos".

${ }^{36}$ Szczegóły liturgiczne tego rytu przedstawia A. Chavasse, La liturgie de la ville de Rome du $V^{e}$ au VIII siècle. Une liturgie conditionée par l'organisation de la vie in Urbe et extra muros, Studia Anselmiana 112, Roma 1993, 16-17.

${ }^{37}$ Por. Cabié, La Lettre „, Si instituta”, s. 51: „Il importe donc que l'unité soit manifestée entre l'Eucharistie stationnale et celle que l'on célèbre dans les quartiers; aussi des acolytes sont-ils chargés d'apporter de l'une à l'autre le fermentum confectionné par l'évêque". 
wionym do posługi na różnych cmentarzach; a prezbiterzy (presbyteri) mają prawo i pozwolenie, aby je konsekrować" ${ }^{38}$.

Zatem ryt fermentum nie powinien być sprawowany tam, gdzie parafie są oddalone od siedziby biskupa; chodzi w tym wypadku o względy praktyczne połączone z wyjątkową troską o sakramenty. Papież uzasadnia tego typu stanowisko także zwyczajem w Rzymie, który nie odnosi się do kapłanów posługujących w miejscach bardziej oddalonych, jak np. na cmentarzach, położonych zwykle poza murami miasta. Stwierdza wreszcie, co nas interesuje w sposób szczególny, że prezbiterzy mają prawo i pozwolenie aby konsekrować, czyli przewodniczyć liturgii eucharystycznej. Innocenty I ukazuje mocny związek w posłudze między biskupem i prezbiterami, który jest wynikiem także wcześniejszych procesów, jakie zachodziły w ramach kształtowania się hierarchii kościelnej. Prezbiterom przypisano znaczący udział w posługach biskupich jak nauczanie, sprawowanie sakramentu chrztu świętego, celebracja Eucharystii i to nie tylko podczas jego obecności, ale także wtedy, gdy go brakowało ${ }^{39}$. Analizowany list wyraźnie potwierdza i umacnia tego typu posługe prezbiterów, sprawowaną w jedności i we współpracy z biskupem.

4. Sacerdos. Chodzi o szczególnie interesujący termin odnoszący się do hierarchii kościelnej wspólnoty rzymskiej początku V w. Słowo znane było już w łacinie klasycznej, w której wskazywało najczęściej na tych, którzy składali święte ofiary, modlili się za innych, opiekowali się rzeczami poświęconymi bóstwu lub umieli odczytywać wieszcze znaki ${ }^{40}$. Zostało przejęte przez autorów chrześcijańskich w odniesieniu do hierarchii Kościoła, jednak z różnymi odcieniami znaczeniowymi, jak to widać np. u Cypriana i Augustyna. Biskup Kartaginy pyta:

„Czy ma coś wspólnego, jak się wydaje, z Chrystusem ten, kto działa przeciw kapłanom (sacerdotes) Chrystusa, kto oddziela się od wspólnoty jego kleru (cleri) i ludu (plebis)? Ten nosi broń przeciw Kościołowi, walczy przeciw urządzeniu Bożemu. Wróg ołtarza, buntujący się przeciw ofierze Chrystusa, zamiast wiary wiarołomca, zamiast religijności świętokradca, nieposłuszny sługa, syn bezbożny, brat nieprzyjazny, wzgardziwszy biskupami (episcopis) i opuściwszy kapłanów (sacerdotibus) Boga, śmie postawić inny ołtarz, nie-

${ }^{38}$ Innocentius I, Epistula ad Decentium w. 98-101, ed. Cabié, s. 26-28: „Quod per parrochias fieri debere non puto quia nec longe portanda sunt sacramenta nec nos per cimeteria diversa constitutis presbiteris destinamus et presbiteri eorum conficiendorum ius habeant atque licentiam".

${ }^{39}$ Por. Cattaneo, Introduzione generale, s. 105-106, nota 41: „Probabilmente anche a Roma nel II sec. esisteva già una pluralità di luoghi di culto (i tituli) presieduti da un presbitero, anche se tali domus ecclesiae avevano poco a che vedere con le attuali parrocchie".

${ }^{40}$ Por. R. Popowski, Kapłaństwo w starożytnym świecie grecko-rzymskim, VoxP 13-15 (19931995) t. 24-29, 29. 
dozwolonymi słowami odmawiać odmienną modlitwę, zbezcześcić prawdę Ofiary Pańskiej przez fałszywe ofiary"41.

Clerus i plebs, jak się dostrzega, stanowią jedną wspólnotę kościelną. Słowo sacerdos pojawia się dwukrotnie; najpierw na oznaczenie biskupów, co jest rzeczą typową dla biskupa Kartaginy, jednakże w drugim przypadku zauważa się pewne rozróżnienie: św. Cyprian mówi o wzgardzeniu biskupami (episcopis) i opuszczeniu kapłanów (sacerdotibus). W tym wypadku dwa terminy nie wydają się być synonimami.

Z kolei św. Augustyn, współczesny papieżowi Innocentemu I, w dziele O Państwie Bożym, komentując odnośne słowa Apokalipsy św. Jana, stwierdza:

„ «Lecz będą kapłanami (sacerdotes) Boga i Chrystusa i będą z Nim królować tysiąc lat» (Ap 20, 6); z pewnością nie mówi jedynie o biskupach i prezbiterach (episcopis et presbyteris), którzy w Kościele już nazywani są w sposób właściwy kapłanami (sacerdotes)" 42 .

Tekst wydaje się klarowny i wskazuje na to, że rzeczownik sacerdos określa biskupów i prezbiterów; w następnych zdaniach św. Augustyn wyjaśnia jednak, że w jakiejś mierze wszyscy wierzący w Chrystusa są kapłanami, ponieważ są członkami jedynego Kapłana ${ }^{43}$.

Wracając do listu Innocentego I, zauważa się, że termin sacerdos pojawia się w nim, jak już było wspomniane, dosyć często, bo w sumie jest użyty, już to w liczbie pojedynczej już to mnogiej, osiem razy. Już w pierwszym zdaniu czytamy:

„Jeśli kapłani Pańscy (sacerdotes) zachowywaliby w całości zwyczaje kościelne, tak jak zostały przekazane przez świętych apostołów, nie byłoby żadnej rozmaitości, żadnej niestałości w samych rytach i konsekracjach"44.

Biorąc pod uwagę zarówno ten fragment jak i inne zdania listu, w których pojawia się rzeczownik sacerdos, można zauważyć, że odnosi się on do tych

${ }^{41}$ Cyprianus, De unitate Ecclesiae catholicae 17, ed. M. Bévenot, SCh 500, Paris 2006, 224-226. „An esse sibi cum Christo videtur qui adversum sacerdotes Christi facit, qui se a cleri eius et plebis societate secernit? Arma ille contra ecclesiam portat, contra Dei dispositionem repugnat. Hostis altaris, adversus sacrificium Christi rebellis, pro fide perfidus, pro religione sacrilegus, inobsequens servus, filius impius, frater inimicus, contemptis episcopis et Dei sacerdotibus derelictis constituere audet aliud altare, precem alteram inlicitis vocibus facere, dominicae hostiae veritatem per falsa sacrificia profanare", tłum. J. Czuj: Św. Cyprian, Pisma, t. 1: Traktaty, POK 19, Poznań 1937, 186.

${ }^{42}$ Augustinus, De Civitate Dei XX 10, ed. D. Gentili, NBA V/3 (Libri XIX-XXII), Roma 1991, 132: „Sed erunt sacerdotes Dei et Christi et regnabunt cum eo mille annis; non utique de solis episcopis et presbyteris dictum est, qui proprie iam vocantur in Ecclesia sacerdotes", thum. własne.

${ }^{43}$ Por. tamże: „Sed sicut omnes christos dicimus propter mysticum chrisma, sic omnes sacerdotes, quoniam membra sunt unius sacerdotis".

${ }^{44}$ Innocentius I, Epistula ad Decentium w. 2-4, ed. Cabié, s. 18: „Si instituta ecclesiastica ut sunt a beatis apostolis tradita integra vellent servare domini sacerdotes, nulla diversitas, nulla varietas in ipsis ordinibus ac consecrationibus haberetur". 
członków wspólnoty wierzących, którzy mają udział w kapłaństwie hierarchicznym, czyli do biskupów i prezbiterów. Można jednak poczynić pewne rozróżnienia. W niektórych zdaniach św. Innocenty, jak się wydaje, odnosi to słowo jedynie do biskupów:

„Nikt inny nie założył Kościołów, jak tylko ci, których czcigodny apostoł Piotr albo jego następcy ustanowili biskupami (sacerdotes)" ${ }^{\text {"45 }}$.

Biorąc pod uwagę przytoczone wcześniej fragmenty listu Innocentego I, ukazujące szczególne miejsce i rolę spełnianą przez biskupów we wspólnocie kościelnej, wydaje się uzasadnioną rzeczą, w tym wypadku, oddanie słowa sacerdotes w języku polskim rzeczownikiem „biskupi”; to oni, w myśli Innocentego I, postrzegani są jako następcy apostołów. W podobnym duchu należy interpretować użycie tego terminu $\mathrm{w}$ innym stwierdzeniu:

„Gdy chodzi o ocenę ciężkości grzechów, osąd należy do biskupa (sacerdotis): czy, biorąc pod uwagę wyznanie pokutującego oraz jego płacz i łzy poprawy, zezwoli na udzielenie rozgrzeszenia wtedy, gdy dostrzeże należyte zadośćuczynienie" ${ }^{\prime 46}$.

Należy ten tekst objaśniać z uwzględnieniem ówczesnych praktyk pokutnych, obejmujących zwykle trzy etapy: podjęcie pokuty za zgodą biskupa i z jego zachęta (correptio); przebywanie przez pewien czas pośród pokutujących (status paenitentium), według uznania biskupa; uroczyste przyjęcie do wspólnoty w Wielki Czwartek przez włożenie rąk biskupich w obecności wspólnoty (reconciliatio ${ }^{47}$. Nie ma pewności, czy stwierdzenie Innocentego I dotyczy właśnie oficjalnego rytu pokutnego, podejmowanego przez tych, którzy zgrzeszyli. Sama wątpliwość przedstawiona przez Decencjusza wskazywałaby jednak na poważne przypadki, co do których osąd był zarezerwowany biskupo$\mathrm{wi}^{48}$. Innocenty posługuje się terminem sacerdos także w zdaniach dotyczących przekazywania znaku pokoju w czasie sprawowania liturgii eucharystycznej:

„Twierdzisz zatem, że niektórzy kapłani (sacerdotes) nakazują ludziom, by [przekazywali sobie znak] pokoju przed modlitwą eucharystyczną albo prze-

${ }^{45}$ Tamże w. 18-20, ed. Cabié, s. 18-20: „Nullum instituisse ecclesias, nisi eos quos venerabilis apostolus Petrus aut eius successores constituerint sacerdotes”.

${ }^{46}$ Tamże w. 116-119, ed. Cabié, s. 28: „Caeterum de pondere aestimando delictorum sacerdotis est iudicare ut attendat ad confessionem paenitentis et ad fletus atque lacrimas corrigentis ac tunc iubere dimitti cum viderit congruam satisfactionem".

${ }^{47}$ Por. C. Vogel, Penitenza, NDPAC III 4014.

${ }^{48}$ Zob. H. Wójtowicz, Terminologia kapłaństwa w literaturze wczesnochrześcijańskiej, VoxP 13-15 (1993-1995) t. 24-29, 66: „Od 2 poł. IV aż do VI wieku wyraz sacerdos oznaczał normalnie biskupa, bez zaznaczania przeciwieństwa w kontekście. Nazwa sacerdos była synonimem wyrazu episcopus, którym określano biskupa, ale stosowano go także okazjonalnie do kapłana w jego władzy kościelnej i w funkcji kultowej”. 
kazują go między sobą; tymczasem należy koniecznie oznajmić, by sobie przekazywać znak pokoju po wszystkim, czego nie powinienem ujawnić"49.

Autor listu nie tyle koncentruje się tutaj na celebransie Eucharystii, ile na wyjaśnieniach związanych ze znakiem pokoju; użyty w każdym razie tutaj rzeczownik sacerdotes wskazuje zarówno na biskupów jak i prezbiterów, szafarzy Eucharystii ${ }^{50}$. Zgromadzenie eucharystyczne, któremu przewodniczy biskup albo prezbiter, jest obrazem wspólnoty zgromadzonej w jedności z Jezusem Chrystusem, który jako Najwyższy Kapłan może realizować w pełny sposób dar Eucharystii. W stwierdzeniu dotyczącym znaku pokoju można dostrzec troskę Innocentego I o to, aby jak najbardziej podkreślić także udział wiernych w Eucharystii; przekazanie znaku pokoju na zakończenie modlitwy eucharystycznej, jak to się działo we wspólnocie rzymskiej, ma wzmacniać w ich sercach sens ich udziału w tajemnicy, którą ten znak zamyka i potwierdza na wzór pieczęci. W podobny sposób należy postrzegać tekst dotyczący wymieniania w czasie liturgii eucharystycznej imion wiernych, zasłużonych w jakiś sposób dla wspólnoty:

„Co się zaś tyczy podawania imion zanim kapłan (sacerdos) odmówi kanon i w swojej modlitwie poleci dary ofiarne tych, których imiona należy wymienić: jak to jest przesadne, także ty sam dzięki swej mądrości to uznasz, abyś nie wymieniał imienia kogoś przed złożeniem Bogu jego ofiary, jako że dla Niego nie ma nic nieznanego" 51 .

Także i w tej wypowiedzi Innocenty koncentruje się nie na celebransie, ale na pewnym elemencie celebracji eucharystycznej; tym razem objaśnia Decencjuszowi, kiedy należy wymieniać imiona tych chrześcijan, żywych czy umarłych, których chcemy w sposób szczególny polecić Bożej łaskawości. Jest rzeczą charakterystyczną, że i w tym przypadku nie posługuje się on ani terminem episcopus, ani presbyter; używając rzeczownika sacerdos wskazuje na ich obydwu jako zwyczajnych szafarzy Eucharystii.

${ }^{49}$ Innocentius I, Epistula ad Decentium w. 38-40, ed. Cabié, s. 20-22: „Pacem igitur asseris ante confecta mysteria quosdam populis imperare, vel sibi inter sacerdotes tradere, cum post omnia quae aperire non debeo pax sit necessario indicenda".

${ }^{50}$ Warto w tym miejscu dodać, że dotykamy kwestii będących ciągle przedmiotem studiów i opracowań, proponujących różne wyjaśnienia. Zob. H. Pietras, Od prezbiteratu do kaptaństwa: ewolucja pojęć i urzędu, „Studia Bobolanum” 3 (2002) 13: „Do końca III w. biskupi i prezbiterzy Kościoła byli postrzegani jako przywódcy, pasterze i nauczyciele wspólnot, którzy mieli przywilej przewodniczenia Eucharystii i udzielenia chrztu; inni mogli robić to ostatnie tylko za ich upoważnieniem. Nic natomiast nie wiadomo o możliwości delegowania do przewodniczenia Eucharystii”; W. Gajewski, Charyzmat, urzad, hierarchia, Kraków 2010, 13: „Jeszcze w II i III w. nazywanie biskupów czy prezbiterów kapłanami jest zjawiskiem rzadkim, choć coraz częściej obecnym”.

${ }^{51}$ Innocentius I, Epistula ad Decentium w. 44-48, ed. Cabié, s. 22: „De nominibus vero recitandis antequam precem sacerdos faciat, atque eorum oblationes quorum nomina recitanda sunt sua oratione commendet quam superfluum sit, et ipse pro tua prudentia recognoscis, ut cuius hostiam necdum Deo offeras, eius ante nomen insinues, quamvis illi incognitum nihil sit". 
5. Diaconus. Termin diaconus pojawia się w liście Innocentego I jedynie dwa razy. Najpierw dostrzegamy go w tekście już przytoczonym, w którym Innocenty I odpowiada na kwestie dotyczące opętanych ${ }^{52}$. Biskup Rzymu referuje, w tym wypadku dosyć dokładnie, pytanie Decencjusza i, co jest rzeczą znacząca, stawia niemal na tym samym poziomie w hierarchii, przynajmniej w odniesieniu do uwalniania opętanych, prezbitera i diakona. Wprawdzie odpowiedź Innocentego I jest negatywna, chodzi bowiem o sprawę bardzo poważną, zarezerwowaną dla biskupa (który ma możliwość udzielenia delegacji), jednak tego typu pytanie i odpowiedź ukazują, że w niektórych przynajmniej kwestiach diakoni mieli podobne uprawnienia do prezbiterów. Co więcej, z dalszego tekstu wynika, że biskup może udzielić delegacji do konkretnego przypadku opętania prezbiterowi albo „pozostałym duchownym” (caeteris clericis), wśród nich, jak można przypuszczać, zwłaszcza diakonom. W innym fragmencie listu rzeczownik diaconus odnosi się do bliskiego współpracownika samego Biskupa Rzymu:

„Ponieważ o tym jak i o innych rzeczach chciał się Twoja Miłość poradzić, syn mój diakon (diaconus) Celestyn dorzucił, że Twoja Miłość przytoczył w liście swoim to, co jest napisane w Liście św. Jakuba apostoła" ${ }^{53}$.

Diakon Celestyn ukazany jest w przytoczonym tekście jako ktoś, kto jest szczególnie bliski biskupowi Rzymu; wskazuje na to jednoznacznie określenie „syn mój diakon”. Z zacytowanego tekstu wynika, że Celestyn pomagał biskupowi Rzymu w prowadzeniu korespondencji i służył radą w wyjaśnianych kwestiach.

Papież Innocenty I w Liście do Decencjusza, biskupa Gubbio odpowiada na pytania dotyczące głównie kwestii liturgicznych i precyzuje kompetencje przedstawicieli ówczesnego duchowieństwa w tej materii. Nawet jeśli bezpośrednio nie określa zadań i uprawnień sprawowanego przez siebie urzędu biskupa Rzymu, ukazuje wyraźnie, że kierowana przez niego wspólnota rzymska wyróżnia się wśród innych szczególnym związkiem ze św. Piotrem; z tego wynika wyjątkowa rola i odpowiedzialność każdorazowego biskupa Rzymu, także w odniesieniu do innych wspólnot wierzących, zwłaszcza Zachodu. Innocenty I skupia się w liście przede wszystkim na obowiązkach i uprawnieniach biskupów (episcopi), których ukazuje jako głównych pasterzy

${ }^{52}$ Tamże w. 102-104, ed. Cabié, s. 28: „De his vero baptizatis qui postea a daemonio, vitio aliquo aut peccato interveniente, arripiuntur, quaesivit dilectio tua si a presbitero vel diacono possint aut debeant consignari”.

${ }^{53}$ Tamże w. 123-126, ed. Cabié, s. 30: „Sane quoniam de hoc sicuti de caeteris consulere voluit dilectio tua, adiecit etiam filius meus Caelestinus diaconus in epistola sua esse a tua dilectione positum illud quod in beati apostoli Iacobi epistola conscriptum est". 
i administratorów Bożych darów. Biskupi są postawieni najwyżej w hierarchii kościelnej; ich rola i funkcje wynikają zarówno z Pisma Świętego jak i ze zwyczaju. Zaraz po biskupach w hierarchii kościelnej wymienieni są prezbiterzy (presbyteri). Innocenty I przypisuje im znaczący udział w posługach jak nauczanie, sprawowanie sakramentu chrztu świętego, celebracja Eucharystii. Jednak bierzmowanie może być udzielane jedynie przez biskupa: prezbiterzy (presbyteri) bowiem, chociaż są kapłanami (sacerdotes), nie mają najwyższego stopnia kapłaństwa. Z kolei słowo sacerdos odnosi się na ogół do biskupów i prezbiterów; niekiedy jednak zarezerwowane jest dla biskupów, np. gdy chodzi o zezwolenie na przyjęcie grzesznika do podjęcia praktyk pokutnych i ponowne jego przyjęcie do wspólnoty w Wielki Czwartek.

\section{EPISCOPUS, PRESBYTER, SACERDOS, DIACONUS: SOME CLARIFICATIONS OF INNOCENT I IN HIS LETTER TO DECENTIUS, BISHOP OF GUBBIO}

\section{(Summary)}

In his Letter to Decentius, Bishop of Gubbio, Pope Innocent I discusses some liturgical questions and specifies the competences of the representatives of the clergy of the time in this regard. First of all, however, he demonstrates the particular link of the community of Rome with the figure of St Peter, which gives rise to the very special role of the Bishop of Rome in relation to other communities, especially in the West. He then concentrates especially on the duties and rights of bishops (episcopi), the principal shepherds and administrators of the divine gifts; on the basis of Sacred Scripture and Tradition he places them at the head of the ecclesiastical hierarchy. Presbyters (presbyteri) are then considered; to them the author of the Letter attributes a significant role especially in teaching and in the celebration of the Eucharist and Baptism. Confirmation is celebrated by the bishop; presbyters, even though they are priests (sacerdotes), do not possess the fullness of the priesthood. The term sacerdos is usually used in reference to bishops and presbyters; however, at times it is reserved to bishops, as, for example, in the discussion on the theme of the beginning of public penance and the admission of the repentant Christian to the community on Holy Thursday.

Key words: diaconus, episcopus, fermentum, presbyter, sacerdos, romana consuetudo, baptism, confirmation, chrism, penance, sign of peace, anointing of the sick.

Slowa kluczowe: diaconus, episcopus, fermentum, presbyter, sacerdos, romana consuetudo, chrzest, bierzmowanie, krzyżmo, pokuta, znak pokoju, namaszczenie chorych. 


\section{BIBLIOGRAFIA}

\section{Źródła}

Annuario Pontificio 2016, Città del Vaticano 2016.

Augustinus, De Civitate Dei, ed. D. Gentili, NBA V/3 (Libri XIX-XXII), Roma 1991.

Cyprianus, De unitate Ecclesiae catholicae, ed. M. Bévenot, SCh 500, Paris 2006, thum.

J. Czuj: Św. Cyprian, Pisma, t. 1: Traktaty, POK 19, Poznań 1937, 171-193.

Hieronymus, Vita Hilarionis, ed. B. Degórski, Hieronymi Opera XV, Roma 2014, 116-180. InNocentius I, Epistula ad Decentium episcopum Egubinum, ed. R. Cabié: La Lettre du Pape Innocent Ier a Décentius de Gubbio (19 Mars 416), Bibliothéque de la Revue d'Histoire Ecclésiastique 58, Louvain 1973.

\section{Opracowania}

CABIÉ R., La Lettre "Si instituta” dans l'histoire de la liturgie, w: La Lettre du Pape Innocent $I^{\text {er }}$ a Décentius de Gubbio (19 Mars 416), ed. R. Cabié, Bibliothéque de la Revue d'Histoire Ecclésiastique 58, Louvain 1973, 35-61.

CABIÉ R., Table des mots latins, w: La Lettre du Pape Innocent I Ir a Décentius de Gubbio (19 Mars 416), ed. R. Cabié, Bibliothéque de la Revue d'Histoire Ecclésiastique 58, Louvain 1973, 64-66.

Cattaneo E., Introduzione generale, w: I ministeri nella Chiesa Antica. Testi patristici dei primi tre secoli, a cura di E. Cattaneo, Letture cristiane del primo millennio 25, Milano 1997, 17-210.

Chavasse A., La liturgie de la ville de Rome du Ve au VIII siècle. Une liturgie conditionée par l'organisation de la vie in Urbe et extra muros, Studia Anselmiana 112, Roma 1993.

Connell M.F., Church and Worship in Fifth-Century Rome: The Letter of Innocent I to Decentius of Gubbio, Text with Introduction, Translation and Notes, Joint Liturgical Studies 52, Cambridge 2002

GaJEwski W., Charyzmat, urzą, hierarchia, Kraków 2010.

J AfFé Ph., Innocentius I, in: Regesta Pontificum Romanorum. Ab condita Ecclesia ad annum post Christum natum MCXCVIII, Editionem tertiam emendatam et auctam iubente Academia Gottingensi, I (A s. Petro usque ad A. DCIV), curavit M. Schütz, Gottingae MMXVI, 122-133.

Lemaire A., Les ministères aux origines de l'Église. Naissance de la triple hiérarchie: évêques, presbytres, diacres, Lectio Divina 68, Paris 1971.

Liber Pontificalis, ed. L. Duchesne, I-II, Paris 1886-1892.

Longosz S., Bibliografia. Kapłaństwo w starożytności chrześcijańskiej, VoxP 13-15 (19931995) t. 24-29, 499-555.

Malchiodi G., La Lettera di S. Innocenzo I a Decenzio vescovo di Gubbio. Breve studio esegetico-storico, Roma 1921.

Monachino V., La Lettera decretale di Innocenzo I a Decenzio vescovo di Gubbio, w: Ricerche sull'Umbria tardoantica e preromanica. Atti del II Convegno di Studi Umbri, Gubbio 24-28 maggio 1964, Gubbio 1965, 211-234.

PIETRAs H., Od prezbiteratu do kaptaństwa: ewolucja pojęć i urzędu, „Studia Bobolanum” 3 (2002) 5-13.

Popowski R., Kapłaństwo w starożytnym świecie grecko-rzymskim, VoxP 13-15 (19931995) t. 24-29, 29-34.

SAXER V. - HeID S., Decenzio di Gubbio, NDPAC I 1344-1345. 
Stanula E., Patrystyczna literatura o kapłaństwie (przeglad bibliograficzny), VoxP 13-15 (1993-1995) t. 24-29, 49-58.

STUDER B., Innocenzo I papa, NDPAC II 2563-2564.

Vogel C., Penitenza, NDPAC III 4012-4017.

Wóstowicz H., Terminologia kapłaństwa w literaturze wczesnochrześcijańskiej, VoxP 1315 (1993-1995) t. 24-29, 59-66. 
